\title{
Cutinase Production by Alternaria alternata Japanese Pear Pathotype and Its Role in Pathogenicity*
}

\author{
Kentaro TANABE**, Syoyo Nishimura** and Keisuke KoHmoto***
}

\begin{abstract}
When grapefruit cutin was added to spore suspension of Alternaria alternata Japanese pear pathotype, significant cutinase activity was observed in the spore-germinated fluid. Cutinase activity was also detected in cutin-containing liquid medium, but not in sucrose-containing medium. Cutinase was produced not only by virulent isolates of this pathotype, but also by the avirulent mutants and saprophytic $A$. alternata in their spore-germinated fluids. Several organophosphorus pesticides which strongly inhibited cutinase were found to have a strong inhibitory effect on lesion formation on pear leaves by the fungus. The cutinase in culture filtrate of the fungus was precipitated by ammonium sulfate, and the precipitate was chromatographed by gel filtration, chromatofocusing and cation exchange columns. The purified fraction expressed clear cutinase activity and appeared as a single protein band with a molecular weight of 32,000 daltons on SDS-PAGE. These data suggested that cutinase production, in addition to AK-toxin production, is essentially required for infection and disease development by this fungus.
\end{abstract}

(Received April 11, 1988)

Key words: Alternaria alternata Japanese pear pathotype, cutinase, pathogenicity, AK-toxin.

\section{INTRODUCTION}

A distinct pathotype (named Japanese pear pathotype) of Alternaria alternata (Fr.) Keissler, the causal agent of the black spot disease of Japanese pear, produces host-selective AK-toxins I and II in cultures and in spore-germinated fluids $\left.{ }^{3,4}\right)$. The chemical structures of AK-toxins I and II were identified as 8 -( $\alpha$-acetylamino- $\beta$-methyl- $\beta$-phenylpropionyloxy)-9,10-epoxy-9-methyl$2 E, 4 Z, 6 E$-decatrienoic acid and its $\beta$-demethyl derivative, respectively ${ }^{7,8)}$. The forms of AKtoxins have been synthesized, confirming these structures'). Further observations were done on the host-selective role of these toxins in pathogenesis which revealed that they act as suppressors of disease resistance only on the host plant ${ }^{4,10)}$. However, the penetration mechanism whereby this occurs is still unclear. Fungi belonging to $A$. alternata infect plants by penetrating unwounded tissues, thus passing the aerial parts of plants covered with cuticle. Recently, it was clearly demonstrated with several plant-pathogenic fungi that these pathogens produce cutinhydrolyzing enzymes, both in vitro and in vivo ${ }^{5}$. Production of cutinase which degrades cutin was induced by pathogens when these were cultured on a medium containing cutin as a sole carbon source ${ }^{5)}$, and this induction was also detected on RNA level'2).

Work was to start to study cutinase production in cultures and in spore-germinated fluids of A. alternata Japanese pear pathotype, and to evaluate the role of cutinase in pathogenesis, in addition to AK-toxin production. Brief reports of portion of this study have been previously published ${ }^{12,18)}$.

\footnotetext{
* Supported in part by Research Grant (No. 62304015) from the Ministry of Education, Science and Culture of Japan.

** Faculty of Agriculture, Nagoya University, Nagoya 464, Japan 名古屋大学農学部

*** Faculty of Agriculture, Tottori University, Tottori 680, Japan 鳥取大学農学部
} 


\section{MATERIALS AND METHODS}

Preparation of spore-germinated fuid. Experiments were done mainly with two pathogenic isolates, No. 15A and TAK 41, and non-pathogenic isolate No. 15B (AK-toxin-less mutant from isolate No. 15A) of $A$. alternata Japanese pear pathotype. In addition, a saprophytic isolate of $A$. alternata $(0-94)$ was also used. Spores of these fungi were prepared as previously reported ${ }^{14)}$. A spore suspension $\left(10^{6}\right.$ spores $\left./ \mathrm{ml}\right)$ was placed on paper towels in a moist plastic chamber and incubated for $20 \mathrm{hr}$ at $20 \mathrm{C}$. After specified incubation periods, sporegerminated fluids were collected by squeezing the papers and then filtrating to remove the spores.

Culture conditions. A. alternata isolates were maintained on potato dextrose agar slants, and used as inoculum. For cutinase production, they were inoculated on cutin-containing media in which cutin powder $(0.5 \mathrm{~g})$ was thoroughly dispersed in $100 \mathrm{ml}$ of a basal mineral medium at $\mathrm{pH} 7.2^{11)}$, and cultured for 10 days at $28 \mathrm{C}$.

Preparation of grapefruit cutin and $\left[{ }^{3} \boldsymbol{H}\right]$ cutin. Grapefruit cutin was prepared as described by Köller et al. ${ }^{6)}$ Unless stated otherwise, cutin to be used was labeled with $\left[{ }^{3} \mathrm{H}\right]$ $\mathrm{NaBH}_{4}{ }^{6}$.

Enzyme assays. Cutinase activity was measured in two ways, using cutin and pnitrophenyl butyrate (PNB) as substrates. The enzyme activity using cutin was measured as described by Köller et al. ${ }^{6}$. $\left[{ }^{3} \mathrm{H}\right]$ Cutin $(0.1 \mathrm{mg})$ was mixed with cold cutin $(2.5 \mathrm{mg})$ and incubated in $2 \mathrm{ml}$ of $0.2 \mathrm{M}$ phosphate buffer ( $\mathrm{pH} 8.5)$ containing $0.5 \%(\mathrm{w} / \mathrm{w})$ Triton X-100 overnight. Cutin was recovered by centrifugation and washed several times with assay buffer ( $50 \mathrm{mM}$ glycine$\mathrm{NaOH}$ buffer, $\mathrm{pH} 9.0$ ) and subsequently incubated with aliquots of the enzyme in a total volume of $1 \mathrm{ml}$ of assay buffer at $30 \mathrm{C}$. The reaction was terminated by filtering the mixture through an absorbent cotton plug in a Pasteur pipette. The filtrate was acidified with $0.1 \mathrm{ml}$ of $12 \mathrm{~N}$ $\mathrm{HCl}$ and extracted with diethyl ether $(1 \mathrm{ml}) 4$ times. The combined ether extracts were dried and the residue was assayed for $\left[{ }^{3} \mathrm{H}\right]$ after addition of $5 \mathrm{ml}$ Scintisol EX-H (Wako Pure Chemical Industries Ltd.). Controls were run with identical reaction mixtures containing no enzyme, and the control values were subtracted from experimental values. The enzyme activity using PNB was measured spectrophotometrically, according to Purdy and Kolattukudy ${ }^{11)}$.

Determination of AK-toxin in spore-germinated fuids. Production of AK-toxin in spore-germinated fluid was determined as previously described $\left.{ }^{3}\right)$. Spore-germinated fluid (50 ml) was acidified with $1 \mathrm{M} \mathrm{NaH} \mathrm{PO}_{4}$ aqueous solution $(5 \mathrm{ml})$ and extracted with diethyl ether. After removal of the ether by evaporation, the residues were subjected to high performance liquid chromatography (HPLC, BIP-I, Japan Spectroscopic Co., Ltd.) equipped with a UV spectrophotometer as a detector. Samples were injected into Finepak SIL-C $\mathbf{C}_{18}$ column (Japan Spectroscopic Co., Ltd.) and eluted with mixture of $60 \%$ methyl alcohol and $1 \%$ acetic acid at a flow rate of $1 \mathrm{ml} / \mathrm{min}$. AK-toxin was detected with wave length of $290 \mathrm{~nm}$.

Assays for inhibitory effect of organophosphorus pesticides on cutinase and lesion formation. Chlorpyrofosmethyl, dichlorvos and profenofos were kindly provided by Kumiai Chemical Industry Co., Ltd. $O$, o-diethyl 2,3-dihydro-3-oxo-2-phenyl-6-pyridazinyl phosphate (OFU-1029) was provided by Mitsui Toatsu Chemical Inc. Each chemical was dissolved in mixture of $1 \%$ acetone and $0.2 \%$ Tween 80 , and its inhibitory effect on cutinase activity was investigated as described above.

The inhibitory effect of the above chemicals on lesion formation was investigated by using detached young leaves of Japanese pear (cv. Nijisseiki). Spores of the pathogenic isolate No. $15 \mathrm{~A}$ were mixed with pesticide solution, and sprayed on the lower surface of half leaves. As controls, the same concentration of spore suspension without pesticides was sprayed on the complementary half leaves. All treated leaves were incubated for $20 \mathrm{hr}$ at $20 \mathrm{C}$ in a moist chamber and the number of black necrotic lesions appearing on each leaf was counted. 
Purification of cutinase. The culture filtrate of a 10-day-old culture of isolate TAK 41 in cutin-containing medium was filtered through filter paper (Toyo No. 2). Granular ammonium sulfate was slowly added until $70 \%$ saturation was obtained. After 2 or $3 \mathrm{hr}$, the precipitates were collected by centrifugation at $20,000 \times g$ for $20 \mathrm{~min}$, dissolved in $50 \mathrm{mM}$ phosphate buffer (pH 8.0) and dialyzed overnight against the same buffer at $5 \mathrm{C}$. The dialyzed solution was concentrated by polyethylene glycol 20,000 and the solution was clarified by centrifugation. The concentrated enzyme solution was chromatographed by Sephacryl S-200 (column size: $1.8 \times$ $80 \mathrm{~cm}$ ). The column was eluted with $50 \mathrm{mM}$ phosphate buffer $(\mathrm{pH} 8.0)$. Each of $5 \mathrm{ml}$ fraction was collected and assayed for cutinase and PNB hydrolase activities, and then the protein concentration was determined by the method of Bradford ${ }^{1)}$. The fractions possessing cutinase activity were concentrated and dialyzed overnight against $25 \mathrm{mM}$ imidazole- $\mathrm{HCl}$ buffer (pH 7.4). The enzyme solution was then applied to a PBE 94 column $(1.2 \times 16 \mathrm{~cm})$ which had been equilibrated in $25 \mathrm{mM}$ imidazole- $\mathrm{HCl}$ buffer ( $\mathrm{pH} \mathrm{7.4)}$ ) and eluted with $200 \mathrm{ml}$ of Polybuffer $74-\mathrm{HCl}$ (pH 4.0). After the elution, the column was eluted with $1 \mathrm{M} \mathrm{NaCl}$. The fractions which possessed cutinase activity were concentrated and dialyzed against $25 \mathrm{mM}$ citrate- $50 \mathrm{mM}$ phosphate buffer ( $\mathrm{pH} 4.5$ ). Finally, the enzyme solution was subjected to a cation exchange column of SP-Sephadex C-25 $(1.8 \times 20 \mathrm{~cm})$, equilibrated in $25 \mathrm{mM}$ citrate-50 mM phosphate buffer $(\mathrm{pH}$ 4.5). Before a stepwise gradient of $0-100 \mathrm{mM} \mathrm{NaCl}$ was applied, the column was washed with $100 \mathrm{ml}$ of the same buffer.

Electrophoresis. SDS-polyacrylamide gel electrophoresis was performed with $10 \%$ polyacrylamide gel and protein was stained with coomassie brilliant blue R-250. Low molecular weight callibration kit from Pharmacia Fine Chemicals was used as a molecular marker.

\section{RESULTS}

Induction of cutinase in spore-germinated fuids and liquid cultures of A. alternata Spore suspension (in $50 \mathrm{mM}$ potassium phosphate buffer, $\mathrm{pH}$ 8.0) of $A$. alternata Japanese pear pathotype (No. 15A) with $0.5 \%$ cutin or sucrose as a sole carbon source was incubated on paper towels in a moist chamber. Spore germination was not affected by these carbon sources. In cutin-added spore suspension, the spores germinated soon after the incubation, and the germination rate was more than $90 \% 8 \mathrm{hr}$ after inoculation (Fig. 1). Significant production of cutinase in the germinated fluids was observed from $8 \mathrm{hr}$ to $24 \mathrm{hr}$ after the incubation. Maximal activity of cutinase reached $20 \mathrm{hr}$ of incubation. In sucrose-added spore suspension, cutinase activity in the germinated fluids was significantly lower than in cutin-added ones. No significant cutinase activity was observed in spore-germinated fluids without any carbon source.

Cutinase activity was also induced in a liquid mineral medium containing cutin as the only carbon source (Fig. 2). Measurable amounts of the enzyme activity could be detected from 6 days of inoculation and it increased markedly afterwards. Although fungal growth did not seem to be affected by the kind of carbon source, no significant activity of cutinase was found in sucrose-containing liquid media.

Involvement of cutinase in lesion formation on Japanese pear by A. alternata

Spores of $A$. alternata Japanese pear pathotype (No. 15A and TAK 41), AK-toxin-less mutant (No. 15B) and saprophyte (0-94) were allowed to germinate in cutin-suspended water and cutinase activities in their respective spore-germinated fluids were measured. All these fungi produced equal amounts of cutinase in their fluids, regardless of their abilities of AK-toxin production or lesion formation on Japanese pear (Table 1).

Among 24 kinds of organophosphorus insecticides employed, four chemicals, chlorpyrifosmethyl, dichlorvos, profenofos and OFU-1029 were found to inhibit significantly cutinase activity (Fig. 3). These chemicals were mixed with spores of isolate No. 15A, and their inhibitory effect to lesion formation was investigated. These chemicals inhibited lesion formation on Japanese pear leaves (Fig. 3). However, they did not inhibit AK-toxin production of germinat- 


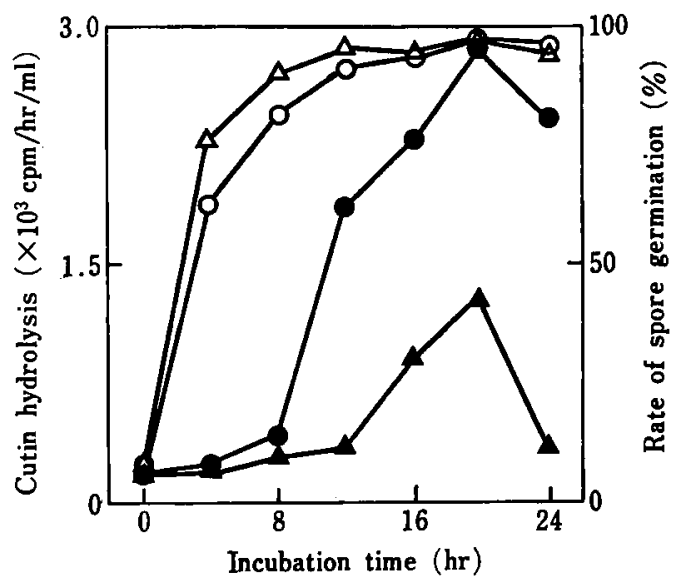

Fig. 1. Induction of cutinase in spore-germinated fluid of $A$. alternata Japanese pear pathotype (No. 15A). As a sole carbon source, cutin and sucrose were added to spore suspension, incubated on paper towels in a moist chamber for indicated times. Rate of spore germination was measured in cutin $(O)$ - and sucrose $(\Delta)$-added spore suspension, respectively. Cutinase activities in cutin ( $(\bullet)$ - and sucrose $(\Delta)$-added spore suspensions were assayed as described in the text.

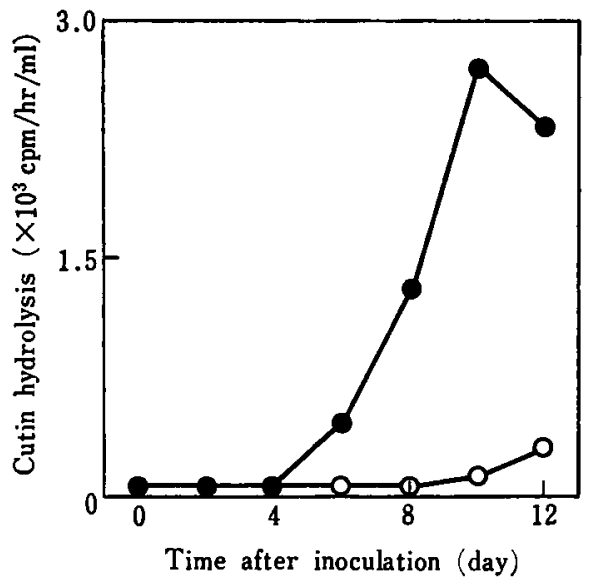

Fig. 2. Induction of cutinase in culture filtrate of $A$. alternata Japanese pear pathotype (TAK 41). As a sole carbon source, cutin ( $O$ ) and sucrose $(O)$ were added to mineral medium, and cultured for indicated times. Cutinase activity was assayed as described in the text.

ing spores, mycelial growth on PDA plates, spore germination and appressorial formation (data are not shown).

\section{Purification of cutinase}

A $70 \%$ saturation of ammonium sulfate in culture filtrate resulted in the precipitation of protein with cutinase activity. The precipitate was fractionated by gel filtration on a Sephacryl S-200 column (Fig. 4). Two peaks showing PNB hydrolase activity were present. Cutinhydrolyzing activity was detectable only in the latter peak.

The cutinase and non-specific esterase activities were not always completely resolved by the gel filtration. Therefore, the fractions containing cutinase activities were pooled and further subjected to PBE 94 column chromatography (Fig. 5). Cutinase activity was eluted before the 
Table 1. Comparison of cutinase activity and AK-toxin I production in spore-germinated fluids, and pathogenicity to Japanese pear leaves among several isolates of $A$. alternata

\begin{tabular}{lccc}
\hline \hline Isolate ${ }^{\text {a) }}$ & $\begin{array}{c}\text { Activity of } \mathrm{b}) \\
\text { cutinase } \\
(\mathrm{cpm} / \mathrm{hr} / \mathrm{ml})\end{array}$ & $\begin{array}{c}\text { Production of } \\
\text { AK-toxin I } \\
(\mathrm{ng} / \mathrm{ml})\end{array}$ & $\begin{array}{c}\text { Pathogenicityc) } \\
\text { (spots/cm }\end{array}$ \\
\hline No. 15A & 2,652 & 949.1 & 56.0 \\
TAK 41 & 2,953 & 324.9 & 29.8 \\
No. 15B & 2,191 & 0 & 0.5 \\
0.94 & 2,836 & 0 & 0.1 \\
\hline
\end{tabular}

a) No. 15A and TAK 41 were pathogenic isolates, and No. 15B was AK-toxin-less mutant of isolate No. 15A. Isolate 0.94 was saprophyte.

b) Determined in cutin-suspended $50 \mathrm{mM}$ potassium phosphate buffer (pH 8.0) $24 \mathrm{hr}$ after inoculation.

c) Spore suspension $\left(10^{6}\right.$ spores $\left./ \mathrm{ml}\right)$ was sprayed on detached young leaves of Nijisseiki pear, and number of necrotic spots was measured $24 \mathrm{hr}$ after inoculation.

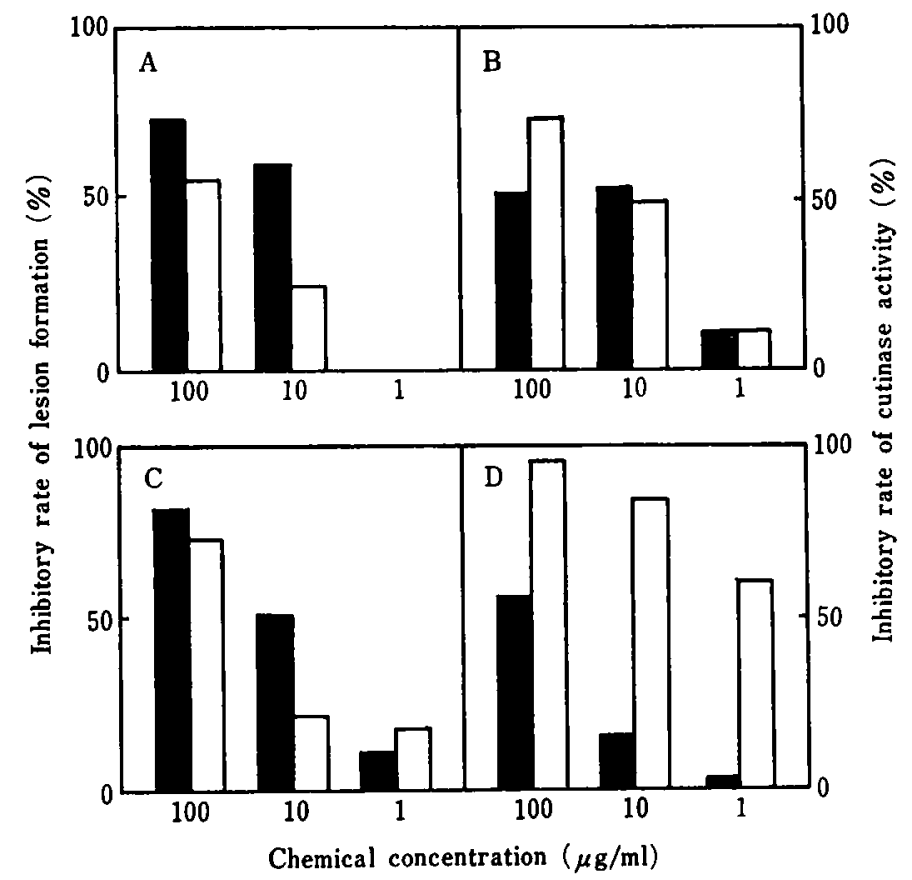

Fig. 3. Inhibitory effects of chlorpyrifosmethyl (A), dichlorvos (B), profenofos (C) and OFU1029 (D) on lesion formation and cutinase activity. All pesticides were adjusted to indicated concentrations, and inhibition of lesion formation $(\boldsymbol{E})$ and cutinase activity ( $\square$ ) were evaluated as described in the text.

pH gradient, but non-specific esterase and phenolic compounds remained on the column. These substances were eluted with $1 \mathrm{M} \mathrm{NaCl}$ after the $\mathrm{pH}$ gradient.

The final purification of cutinase was accomplished by SP-Sephadex cation exchange chromatography (Fig. 6) which resulted in elution of a single protein peak. This possessed the ability to hydrolyze both cutin and PNB.

\section{Electrophoresis}

The purity of cutinase from $A$. alternata was examined using SDS-polyacrylamide gel electrophoresis (Fig. 7). Cutinase could be purified with PBE 94 chromatography containing only 


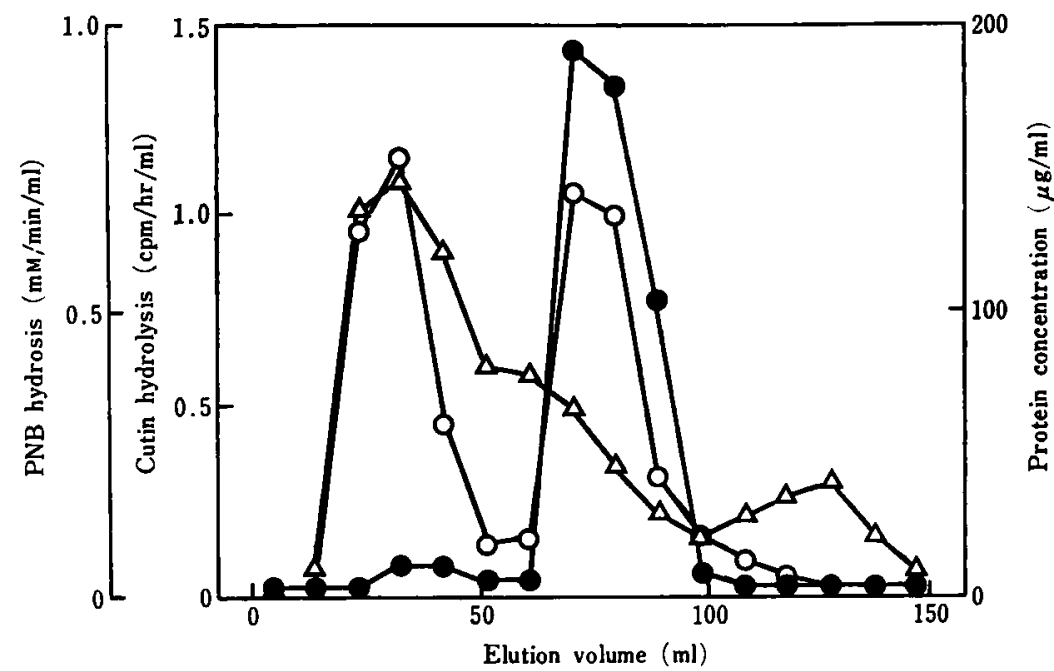

Fig. 4. Sephacryl S-200 chromatography of the protein fraction precipitated by ammonium sulfate from the culture filtrate of $A$. alternata (TAK 41). The protein was eluted with $50 \mathrm{mM}$ phosphate buffer (pH 8.0). Cutinase (O) and PNB hydrolase (O) activity, and protein concentration $(\Delta)$ were assayed as described in the text.

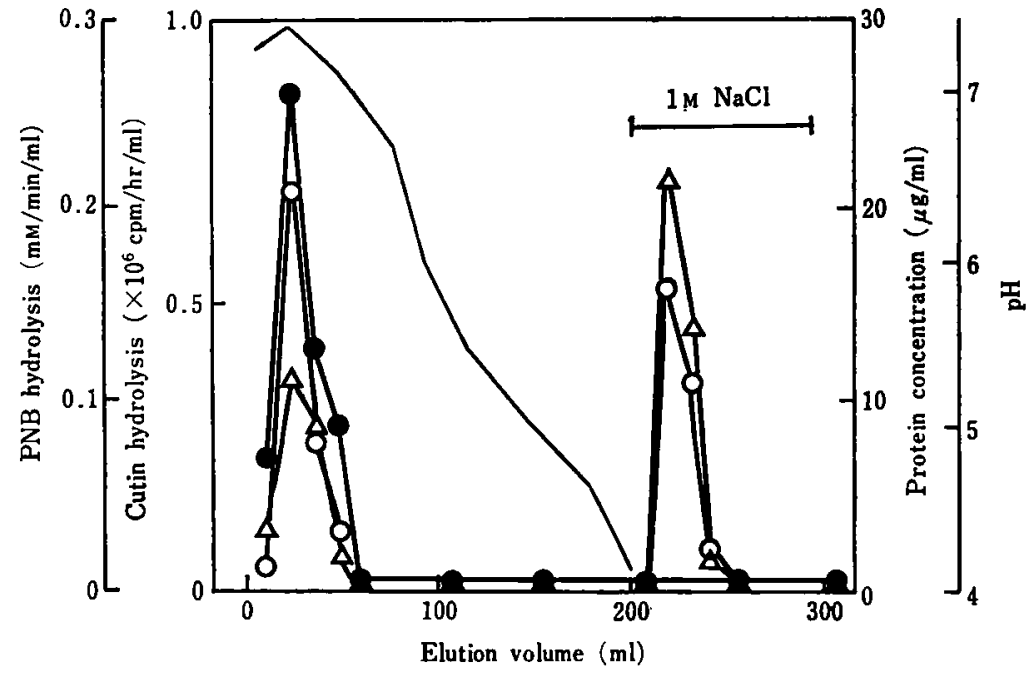

Fig. 5. PBE 94 column chromatography of a cutinase fraction obtained from the Sephacryl S-200 step. The column was equilibrated with in $25 \mathrm{mM}$ imidazole- $\mathrm{HCl}$ buffer (pH 7.4) and the protein was eluted with $200 \mathrm{ml}$ of Polybuffer 74- $\mathrm{HCl}$ (pH 4.0). After elution, the column was washed with $1 \mathrm{M} \mathrm{NaCl}$. Cutinase (O) and PNB hydrolase (O) activities, protein concentration $(\Delta)$ and $\mathrm{pH}(-)$ of the fractions were assayed as described in the text.

small amount of additional contaminants. After chromatography on SP-Sephadex, a single protein band possessing cutinase activity was detected by gel electrophoresis. The molecular weight of cutinase was determined by SDS-polyacrylamide gel electrophoresis (Fig. 8). From a linear plot of mobility vs. log molecular weight of standard proteins, the cutinase was estimated to have a molecular weight of 32,000 daltons. 


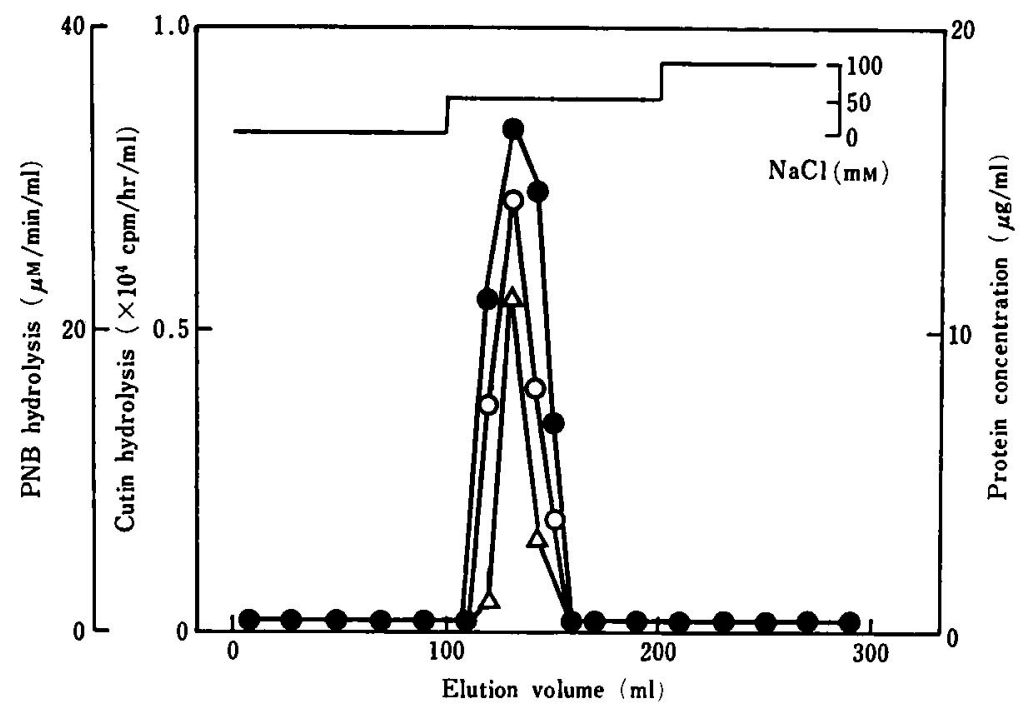

Fig. 6. SP-Sephadex chromatography of a cutinase fraction obtained from the PBE 94 step. The protein was eluted with $50 \mathrm{mM}$ citrate- $25 \mathrm{mM}$ phosphate buffer (pH 4.5) and $\mathrm{NaCl}$ gradient was carried out stepwise $(0 \sim 100 \mathrm{mM})$. Cutinase $(\bullet)$ and PNB hydrolase $(O)$ activities, and protein concentration $(\triangle)$ were assayed as described in the text.

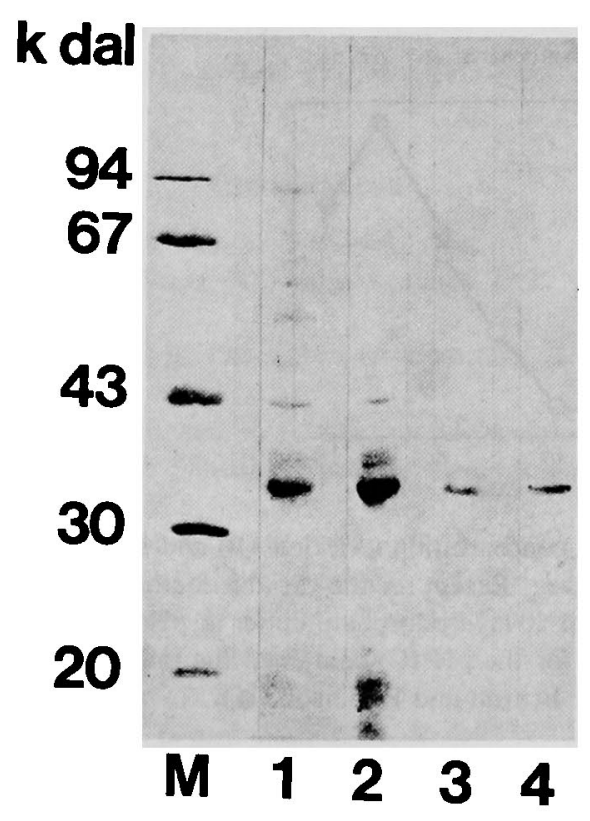

Fig. 7. SDS-Polyacrylamide gel electrophoresis of each purification step of cutinase. Experimental conditions are described in the text. Lane M: Molecular weight marker. Lane 1: Ammonium sulfate precipitation. Lane 2: Fraction obtained from Sephacryl S-200 step. Lane 3: Fraction obtained from PBE 94 step. Lane 4: Fraction obtained from SP-Sephadex step. 


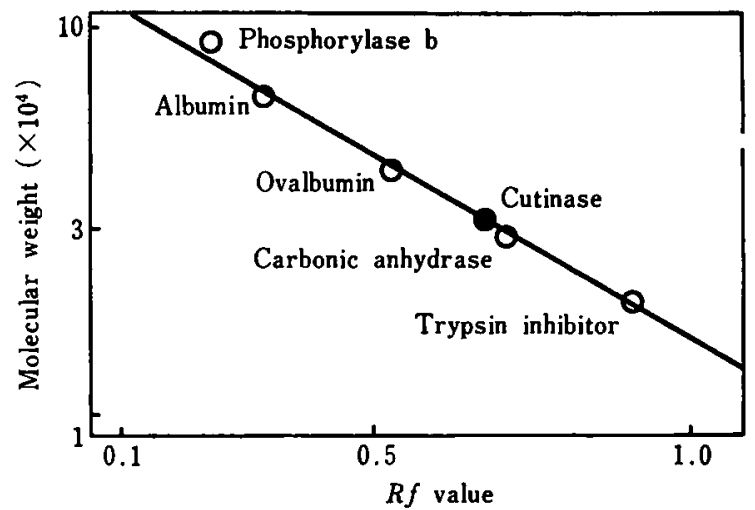

Fig. 8. Molecular weight determination of cutinase by SDS-polyacrylamide gel electrophoresis. Experimental conditions were described in the text.
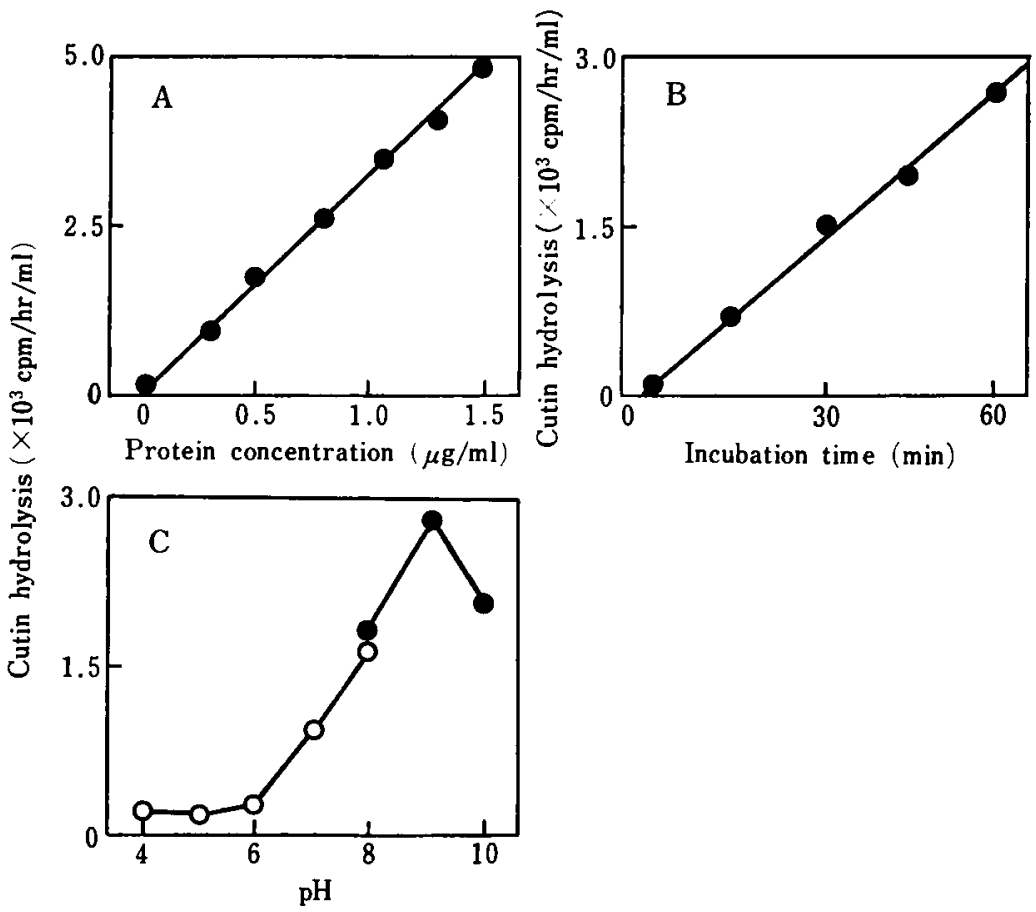

Fig. 9. Effects of protein concentration (A), time (B) and $\mathrm{pH}(\mathrm{C})$ on the hydrolysis of $\left[{ }^{3} \mathrm{H}\right]$ cutin by purified cutinase. Except for the variable factor, the assay was carried out with $1 \mu \mathrm{g}$ cutinase in $1 \mathrm{ml}$ of $50 \mathrm{mM}$ phosphate buffer at pH 9.0 incubated for $1 \mathrm{hr}$ at $30 \mathrm{C}$. The reaction mixture for the $\mathrm{pH}(\mathrm{C})$ contained the indicated buffer: $25 \mathrm{mM}$ citrate- $50 \mathrm{mM}$ phosphate (O) or Britton and Robinson (O).

\section{The effects of time, $\mathrm{pH}$ and protein concentration on hydrolysis by cutinase}

The purified cutinase was characterized using $\left[{ }^{3} \mathrm{H}\right]$ cutin as a substrate. The assay involved the enzymatic release of soluble cutin monomers and oligomers from the insoluble $\left[{ }^{3} \mathbf{H}\right]$ cutin substrate ${ }^{6}$. With increasing enzyme concentration and reaction time, a linear increase in the rate of cutin hydrolysis occurred (Figs. 9A and B). A study on pH dependency could be observed that very low rates of hydrolysis occurred below pH 7.0, but with increasing pH from 7.0 to 10.0 , followed a significant increase in activity, too (Fig. 9C). 


\section{DISCUSSION}

As was found by others with several plant-pathogenic fungi ${ }^{5}$, also $A$. alternata causing a black spot disease on Japanese pear produced cutinase, when cutin was used as the carbon source in the culture medium. Pathological importance was the fact that in the presence of cutin germinating spores of the fungus could be induced to produce cutinase. Cutinase production is essentially required for the fungal penetration into cutin-containing aerial surface of the host plant. Results indicated that the cutinase activity occurs shortly after the formation of a germ tube, suggesting that it plays an important role in the aggressiveness of the fungus. Our previous data also indicated the importance of AK-toxin production by germinating spores of virulent isolates, but not by avirulent ones ${ }^{4}$. Presumably, both productions of cutinase and AK-toxin serve as an aggressive factor of the fungus.

In contrast to AK-toxin production, however, cutinase production was found in all isolates of A. alternata used, regardless of their pathogenicity. But if cutinase production of virulent isolates was inhibited by organophosphorus chemicals during spore germination, pathogenicity of the pathogen could be reduced markedly. Therefore, this study indicates for the first time that host-selective toxin producing plant pathogens need cutinase activity as a further additional factor of their pathogenicity besides toxin production.

Purification of cutinase from culture filtrate of the fungus was carried out. The cutinase was isolated in the same way as described previously ${ }^{5}$, except that a PBE 94 column for chromatofocusing was used for removing non-specific esterase and phenolic compounds. Since the cutinase of $\boldsymbol{A}$. alternata was easily inactivated at $\mathrm{pH} 9.0$ on QAE-Sephadex, a PBE 94 column was employed. On this column, the cutinase was eluted at a neutral $\mathrm{pH}$ range. The molecular weight of cutinase purified in this experiment was estimated as 32,000 daltons. This value was almost similar to that reported by Kolattukudy5). Breakdown of grapefruit $\left[{ }^{3} \mathrm{H}\right]$ cutin by the purified cutinase was optimal at pH 9.0, similar to cutinases ${ }^{5)}$ obtained by other sources.

\section{Literature cited}

1. Bradford, M.M. (1976). Anal. Biochem. 72: 248-254.

2. Brandi, M.L., Fitzpatrick, L.A., Coon, H.G. and Aurbach, G.D. (1986). Proc. Natl. Acad. Sci. USA 83: 1709-1713.

3. Hayashi, N., Tsuge, T., Nishimura, S., Otani, N. and Kohmoto, K. (1986). Ann. Phytopath. Soc. Japan 52: 528 (Abstr.).

4. Kohmoto, K., Otani, H. and Nishimura, S. (1987). In Molecular Determinants of Plant Diseases (Nishimura, S. et al. eds.). Japan Scientific Societies Press, Tokyo and Springer-Verlag, Berlin. pp. 127-143.

5. Kolattukudy, P.E. and Crawford, M.S. (1987). Jbid. pp. 75-95.

6. Köller, W., Allain, C.R. and Kolattukudy, P.E. (1982). Physiol. Plant Pathol. 20: 47-60.

7. Nakashima, T., Ueno, T. and Fukami, H. (1982). Tetrahedron Lett. 23: 4469-4472.

8. Nakashima, T., Ueno, T., Fukami, H., Taga, T., Masuda, K., Otani, H., Kohmoto, K. and Nishimura, S. (1986). Agri. Biol. Chem. 49: 807-815.

9. Nakatsuka, S., Feng, B.N., Goto, T. and Nishimura, S. (1987). Nippon Nogeikagaku Kaishi 61 : 745 (Abstr.).

10. Nishimura, S. (1987). In Molecular Determinants of Plant Diseases (Nishimura, S. et al. eds.). Japan Scientific Societies Press, Tokyo and Springer-Verlag, Berlin. pp. 11-26.

11. Purdy, R.E. and Kolattukudy, P.E. (1973). Arch. Biochem. Biophys. 159: 61-69.

12. Tanabe, K., Nishimura, S., Tsuge, T., Kobayashi, H. and Kohmoto, K. (1987). Ann. Phytopath. Soc. Japan 53: 101 (Abstr.).

13. Tanabe, K., Nishimura, S., Tsuge, T. and Kohmoto, K. (1987). Ibid. 53: 392 (Abstr.).

14. Tsuge, T., Nishimura, S., Omura, S., Kohmoto, K. and Otani, H. (1985). Ibid. 51: 277-284. 


\section{和 文 摘 要}

田辺憲太郎・西村正暘・甲元啓介 : ナシ黒斑病菌が誘導生成するクチナーゼの純化と病原性哞現にキけける 役割

ナシ黒斑病菌の宿主侵入機構を解明するために，植物の最外層を構成するクチンに対する本菌の醉素的分 解について調べた。本菌の分生胞子㗭濁夜に，常法によりクレープフルーツ果皮より調製したクチンを添加 すると，その胞子発芽液中に顕著なクチナーセ活性が認められた。しかし，ショ糖添加の場合にはその活性

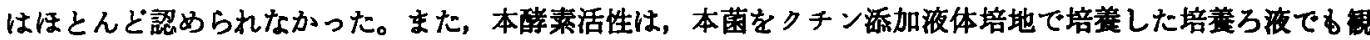
察されたが、ショ糖添加培地ではほとんど認められなかった。このようなクチナーゼの誘導生成は，本菌の AK 毒素生成失活菌や腐生菌についても認められた。なお，クチナーセ活性は，数種の有機りん化合物によ り強く阻害された。これらの有機りん化合物は，菌の胞子発芽には影䡒することなく，二十世紀葉に対する 本菌の病斑形成を著しく抑制した。そこで，本菌が生成するクチナーゼの諸性質を知るため，クチン添加培 地で培着した培着ろ液を硫安塩析し，得られた沈殿について，ゲルろ過，クロマトフォーカシングおよび陽 イオン交换クロマトダラフィーなどによってクチナーゼの純化を行った。その結果，最終的には，クチナー ぜ蛋白質を SDS-PAGE で，分子量約 32,000 の単一バンドとして純化することができた。以上の結果よ り,クチナーゼは AK 毒素とともに，本菌の病原性発現に必要であることが示された。 